\title{
A Community-Based Assessment of Nutritional Status among the Childbearing Age Women's in the Rural Areas of Karnataka
}

\author{
Ms. Fouziya Anjum ${ }^{1 *}$, Dr. Gulappa Devagappanavar ${ }^{2}$ \\ ${ }^{1}$ Master of Public Health Scholar, School of Environmental Science, Public Health and Sanitation Management \\ ${ }^{2}$ Guest Faculty, Department of Public Health, Karnataka State Rural Development and Panchayat Raj University, Gadag, Karnataka India
}

DOI: $10.36348 /$ sjnhc.2020.v03i09.004 | Received: 19.09.2020 | Accepted: 27.09.2020 | Published: 30.09 .2020

*Corresponding author: Ms. Fouziya Anjum

Abstract

Background: According to the World Health Organization, consuming a healthy diet throughout the life-course helps to prevent malnutrition in all its forms as well as a range of non-communicable diseases and conditions. The health of an individual is known to be influenced by his/ her nutritional status. People are now consuming more foods high in energy, fats-free sugars and salt/sodium, and many people do not eat enough fruits, vegetables and dietary Fibre such as whole grains. The exact makeup of a diversified balanced and healthy diet will vary depending on individual characteristics, cultural context, locally available foods and dietary customs. Objectives: To assess the nutrient intake and measuring the nutritional status among the women in childbearing age at the rural areas. Methodology: A cross-sectional study was conducted to assess the dietary intake and the nutritional status of the rural women in the five different villages of Gadag district, Karnataka. Their socio-demographic details, food intake related data were collected using a questionnaire. 24 Hour dietary recall was calculated using nutrient composition table and their nutritional status was calculated using BMI (Body Mass Index). Results: 105 women were interviewed. Majority of participants were of secondary school (32.38\%), middle school (28.57\%) and a majority of them were housewives. Majority of the participants (88.57\%) energy intake was less than the recommended, all the 105 participants (100\%) protein intake was less than $1 \mathrm{gm} / \mathrm{kg} / \mathrm{body}$ weight, majority of them consumed more fat $(72.38 \%)$, sodium intake of all the participants $105(100 \%)$ were more. The nutrient intake was calculated using a nutrition composition table from the ICMR (Indian Council of Medical Research), NIN (National Institute for Nutrition), Hyderabad. And the majority of their nutritional status (BMI) were normal (51.42\%). Majority of the food groups consumed daily by the participants were cereals $(96.19 \%)$, followed by pulses $(64.76 \%)$ which were consumed majorly on $2-3$ times in a week. Fruits $(45.71 \%)$ and vegetables $(63.80 \%)$ were consumed every week. Milk and milk products were consumed daily $(87.61 \%)$. Conclusion: The main food groups consumed daily were cereals followed by pulses. The energy, protein intake was less and fat content was more than the recommended and nutritional status was normal among half of the study population.

Keywords: Body mass index, dietary intake; 24 - hour dietary recall; nutritional status; Childbearing age; Women's Nutritional status.

Copyright @ 2020: This is an open-access article distributed under the terms of the Creative Commons Attribution license which permits unrestricted use, distribution, and reproduction in any medium for non-commercial use (NonCommercial, or CC-BY-NC) provided the original author and source are credited.

\section{INTRODUCTION}

In the Nutrition in Public Health, Handbook for Developing Programs and Services (2006) mentioned that assessment of public health nutrition problems is very important to address the nutritional issues like undernutrition, anaemia and over nutrition and its consequences [1].

As per the Food and agriculture organization, India is home to $25 \%$ of the world's hungry population and 194.6 million undernourished people for the period of 2014-2016. Concerning food consumption, urban women are reported to have better access to a variety of food items. India is known for its diversity in culture and believes, so also their eating behaviors, especially the people from coastal regions are known to have different dietary habits. A healthy dietary habit helps an individual to stay fit and well throughout his life [2].

Despite the good economic performance, with over 200 million people who are food insecure, India is home to the largest number of hungry people in the world. The National Food Survey records of household food purchases and information concerning the dietary pattern of the population, obtained from estimates of total food consumption in the UK showed that the 
nutritional value of the household diet exceeded the recommended daily intake for the majority of nutrients, at least until the end of 1973. Though dietary factors are implicated in chronic disease risk, assessment of dietary intake has limitations, including problems with a recall of complex food intake patterns over a long period [3].

The United States of America, the former Union of Soviet Socialist Republics and Australia. Compared to an average person in these regions and countries of the world, an average Indian consumes only about $2 / 3 \mathrm{rd}$ of the calories, about half the proteins, and around $1 / 4$ th the fats. Nutrition theorists believe that the total number of calories available in India is marginally higher than what is essential for the upkeep of the Indian population at a normal level of activity [4].

Among the Indian population, about $28 \%$ in the rural and $26 \%$ in the urban areas are estimated to be 2 below the poverty line, which is defined as the expenditure needed to obtain, on an average, $2400 \mathrm{Kcal}$ per capita per day in the rural areas and $2100 \mathrm{Kcal}$ in urban areas [5].

The world continues to face major challenges in achieving food security. In the context of the recent food price crises, the importance of food security in various facets of society has been emphasized. Although food security is essential to ensure adequate nutrition and prevent hunger, the concepts of food security, optimal nutrition and lack of hunger and undernutrition are interlinked but not synonymous. Food security is necessary to maintain an optimal nutritional status, and core to its definition is the requirement for nutritious food, which refers not only to sufficient quantities of food (in terms of calories) but also to sufficient quality (in terms of variety and micronutrient content) [6].

Health and nutrition are the most important contributory factors for human resource development in the country. Ensuring food security is an issue of great importance for Asian countries including India. India represents almost 17.53 per cent of the world's population and it will surpass China by 2030 with the population growth rate at 1.58 per cent. India is predicted to have more than 1.53 billion people by the end of 2030 [7].

The diet of early humans was said to be highly varied i.e., it had low fat and high fiber, coupled with higher levels of physical activity. After about 10-12,000 years, industrial revolution and $2^{\text {nd }}$ agricultural revolution began which lead to a greater shift in dietary pattern. Such diets were said to contain high fat, refined carbohydrate and low fiber. There are several factors that have been associated with the occurrence of malnutrition particularly among women such as the socio economic status, culture, demography and dietary characteristics [8].

\section{MATERIALS AND METHODS}

Study settings: Gadag is a district of Karnataka which has 60 villages and two towns. In which five villages were selected for the study to conduct. Those five villages were Binkadakatti, Hulkoti, Kalasapur, Kurthkoti, Nagavi. Binkadakatti and Hulkoti are urbanized when compared to the other three villages.

Study design: A cross-sectional study was conducted to assess the dietary intake and the nutritional status of the rural women of childbearing age. The data was collected using a quantitative method to assess the dietary intake and the nutritional status of women under childbearing age, this study was conducted from the time of July 2019 to September 2019.

Study participants: women who are under the childbearing age of $15-45$ years have participated.

Variables: Socio-demographic variables \& major nutrient intake, lifestyle and their nutritional status.

Data sources: It is a purely quantitative method; primary data was collected using a questionnaire and checklist. And the nutrient intake was assessed through nutrient consumption table. A pretested questionnaire was used to collect information regarding age, education qualification, head of the family education, income, socioeconomic status, 24hour dietary recall, nutritional status through BMI (Body Mass Index) by taking the height and weight and then calculating the BMI using below mentioned formula. BMI Formula: Weight $(\mathrm{kg}) /[\text { height }(\mathrm{m})]^{2}$

\section{Sampling technique and Study size}

A total of 29 wards in 5 villages were listed with population and calculated. A sampling interval was calculated by dividing the total population by 15 . In each of the cluster $1^{\text {st }}$ cluster was identified by a random number of 4 digits as the sample interval was 3142 . The random number was 1317 which fell in $1^{\text {st }}$ ward of Binkadakatti subsequent cluster were identified by adding sample interval of 3142 . In each cluster, the total number of households in each cluster were divided by 7 as that many other samples were calculated to get a total of 105 beneficiaries. After identifying $1^{\text {st }}$ household visited all the other households by tallying marking the households and a detailed interview was done on the Childbearing age women's.

\section{Quantitative variables}

Women who had participated in the study were taken as an independent variable. Their age, height, weight, BMI, 24-hour dietary recall, were measured using international units. 


\section{Statistical method}

Data was entered into an Excel sheet and analysed using v20 SPSS software, and the results were expressed using frequencies and percentages to assess the dietary recall and nutritional status among women of childbearing age.

\section{Ethical committee approval}

Ethical committee approval obtained from the Ethics committee of Karnataka State Rural Development and Panchayat Raj University, Gadag.

\section{RESULTS}

Table-1: Socio demographic details of the study participants

\begin{tabular}{|c|c|c|}
\hline Demographic details & Frequency $($ no=105) & Percentage $(\%)$ \\
\hline \multicolumn{3}{|l|}{ Age group ( years) } \\
\hline$<$ less than 20 & 14 & $13.33 \%$ \\
\hline $21-25$ & 41 & $39.04 \%$ \\
\hline $26-30$ & 26 & $24.76 \%$ \\
\hline $31-35$ & 11 & $10.47 \%$ \\
\hline $36-40$ & 12 & $11.42 \%$ \\
\hline$>41$ & 1 & $0.95 \%$ \\
\hline \multicolumn{3}{|l|}{ Education qualification - } \\
\hline Illiterate & 11 & $10.47 \%$ \\
\hline Primary school & 14 & $13.33 \%$ \\
\hline Middle school & 30 & $28.57 \%$ \\
\hline Secondary school & 34 & $32.38 \%$ \\
\hline Intermediate/diploma & 3 & $2.85 \%$ \\
\hline Graduate & 7 & $6.66 \%$ \\
\hline Professional & 6 & $5.71 \%$ \\
\hline \multicolumn{3}{|l|}{ Religion } \\
\hline Hindu & 89 & $84.76 \%$ \\
\hline Muslim & 16 & $15.23 \%$ \\
\hline Others & 0 & 0 \\
\hline Marital Status & - & \\
\hline Married & 84 & $80 \%$ \\
\hline Unmarried & 20 & $19.04 \%$ \\
\hline Divorcee & 1 & $0.95 \%$ \\
\hline \multicolumn{3}{|l|}{ Head of the family } \\
\hline Male & 93 & $88.57 \%$ \\
\hline Female & 12 & $11.42 \%$ \\
\hline \multicolumn{3}{|l|}{ Head of the family education } \\
\hline Illiterate & 44 & $41.90 \%$ \\
\hline Primary school & 15 & $14.28 \%$ \\
\hline Middle school & 19 & $18.09 \%$ \\
\hline Secondary school & 17 & $16.19 \%$ \\
\hline Intermediate/diploma & 2 & $1.904 \%$ \\
\hline Graduate & 6 & $5.71 \%$ \\
\hline Professional & 2 & $1.90 \%$ \\
\hline \multicolumn{3}{|l|}{ Occupation } \\
\hline Professional & 5 & $4.76 \%$ \\
\hline Technicians and associate professional & 3 & $2.85 \%$ \\
\hline Skilled Workers and Shop \& Market Sales Workers & 9 & $8.57 \%$ \\
\hline Skilled Agricultural \& Fishery Workers & 52 & $49.52 \%$ \\
\hline Plant \& Machine Operators and Assemblers & 13 & $12.38 \%$ \\
\hline elementary occupations & 16 & $15.23 \%$ \\
\hline Unemployed & 4 & $3.80 \%$ \\
\hline \multicolumn{3}{|l|}{ Income (INR) } \\
\hline$\geq 78,063$ & 0 & 0 \\
\hline $39,033-78,062$ & 1 & $0.95 \%$ \\
\hline $29,200-39,032$ & 5 & $4.76 \%$ \\
\hline $19,516-29,199$ & 14 & $13.33 \%$ \\
\hline $11,708-19,515$ & 11 & $10.47 \%$ \\
\hline $3,908-11,707$ & 35 & $33.33 \%$ \\
\hline$\leq 3,907$ & 39 & $37.14 \%$ \\
\hline \multicolumn{3}{|l|}{ SES Scale } \\
\hline Upper class & 1 & $0.95 \%$ \\
\hline Upper middle & 14 & $13.3 \%$ \\
\hline Lower middle & 25 & $23.80 \%$ \\
\hline Upper lower & 65 & $61.90 \%$ \\
\hline Lower & 0 & 0 \\
\hline
\end{tabular}




\section{Socio-demography of the participants}

The study includes 105 women who were under the childbearing age (15 - 45 years). As per table 1 , most of the participants were under the age group of $21-25$ years $(39.04 \%)$. Most of the participants had completed secondary school $(32.38 \%)$. Majority of the participants belongs to the Hindu family, followed by Muslim. Most of the participant's head of the family's education background were illiterate followed by middle school and the majority of them were skilled agricultural. Male dominancy is more when compared to female in the families. And as per their income, almost $70 \%$ of the family's income was less than $11000 /-$ and the majority of the participants belongs to the upper lower-class (table 1).

Table-2: 24-hour dietary recall of the participants

\begin{tabular}{|c|c|c|c|c|c|c|c|c|c|c|}
\hline \multirow{3}{*}{$\begin{array}{l}\text { Age } \\
\text { group } \\
\text { (Years) }\end{array}$} & \multicolumn{10}{|c|}{ Dietary intake of participants $(n=105)$} \\
\hline & \multicolumn{3}{|c|}{ Energy(kcal) } & \multicolumn{2}{|c|}{ Protein $(\mathrm{gm})$} & \multicolumn{3}{|c|}{ Fat (gm) } & \multicolumn{2}{|c|}{ Sodium (mg) } \\
\hline & $\begin{array}{l}<1500 \mathrm{kc} \\
\mathrm{al}\end{array}$ & $\begin{array}{l}1500- \\
2000 \\
\text { Kcal }\end{array}$ & $\begin{array}{l}>2000 \\
\text { Kcal }\end{array}$ & $\begin{array}{l}<1.0 \mathrm{gm} / \\
\mathrm{kg} / \text { body } \\
\mathrm{wt}\end{array}$ & $\begin{array}{l}\text { Recommen } \\
\text { ded } \\
1.0 \mathrm{gm} / \mathrm{kg} / \\
\text { body wt }\end{array}$ & $<25 \mathrm{gm}$ & $\begin{array}{l}25- \\
30 \mathrm{gm}\end{array}$ & $>30 \mathrm{gm}$ & $\begin{array}{l}<150 \\
0 \mathrm{mg}\end{array}$ & $\begin{array}{l}1500- \\
2000 \mathrm{mg}\end{array}$ \\
\hline $\begin{array}{l}<\text { less } \\
\text { than } 20\end{array}$ & 14 & - & - & 14 & - & 5 & - & 9 & - & 14 \\
\hline $21-25$ & 36 & 5 & - & 41 & - & 6 & 6 & 29 & - & 41 \\
\hline $26-30$ & 24 & 2 & - & 26 & - & 6 & - & 20 & - & 26 \\
\hline $31-35$ & 9 & 2 & - & 11 & - & 1 & 3 & 7 & - & 11 \\
\hline $36-40$ & 9 & 2 & 1 & 12 & - & 1 & - & 11 & - & 12 \\
\hline$>41$ & 1 & & & 1 & - & & 1 & & & 1 \\
\hline & $\begin{array}{l}93(88.57 \\
\%)\end{array}$ & $\begin{array}{l}11(10.47 \\
\%)\end{array}$ & $\begin{array}{l}1(0.95 \\
\%)\end{array}$ & $\begin{array}{l}105(100 \\
\%)\end{array}$ & - & $\begin{array}{l}19(18.09 \\
\%)\end{array}$ & $\begin{array}{l}10(9.52 \\
\%)\end{array}$ & $\begin{array}{l}76(72.38 \\
\%)\end{array}$ & & $\begin{array}{l}105(100 \\
\%)\end{array}$ \\
\hline
\end{tabular}

The above-mentioned table says about the nutritional imbalance between the participants as per their age group. 105 participants participated in the study. As per the above table, hardly $10.47 \%$ of the participants consumed the recommended amount of energy. About $88.57 \%$ of the participants consumed less than the $1500-2000 \mathrm{Kcal}$ which is recommended and they were mostly from the age group of 21 to 30 years of age group. As per the nutrient protein, all the
105 participants' protein intake is less than the recommended which is $1.0 \mathrm{gm} / \mathrm{kg} /$ body wt., And they were majorly from the age group of $21-30$ years of age. Majority of the participants $76(72.38 \%)$ fat consumption is more than the recommended which is more than $>30 \mathrm{gm}$ and only about $10(9.52 \%)$ of them consumed as per recommended. As per the Sodium, all the 105 participants' sodium intake is more than $1500-$ $2000 \mathrm{mg}$ as sodium is being used every day in the diet.

Table-3: Average frequency of consumption of food groups in a month:

\begin{tabular}{|l|l|l|l|l|}
\hline \multirow{2}{*}{ Food groups } & \multicolumn{3}{|c|}{ Frequency of foods consumed } \\
\cline { 2 - 5 } & Daily & $\begin{array}{l}\mathbf{2 - 3} \text { times in a } \\
\text { week }\end{array}$ & Weekly Once & Less often \\
\hline Cereals, millets and grains & $101-(96.19 \%)$ & $4-(3.80 \%)$ & 0 & 0 \\
\hline Pulses and legumes & $3-(8.57 \%)$ & $68-(64.76 \%)$ & $34-(32.38 \%)$ & 0 \\
\hline Green leafy vegetables & $17-(16.19 \%)$ & $60-(57.14 \%)$ & $28-(26.66 \%)$ & 0 \\
\hline Other vegetable group & 0 & $38-(36.19 \%)$ & $67-(63.80 \%)$ & 0 \\
\hline Fruits group & $4-(3.80 \%)$ & $15-(14.28 \%)$ & $48-(45.71 \%)$ & $38-(36.19 \%)$ \\
\hline Nuts and oil seeds group & $20-(19.04 \%)$ & $76-(72.38 \%)$ & $9-(8.57 \%)$ & 0 \\
\hline Condiments and spices & $67-(63.80 \%)$ & $36-(34.28 \%)$ & $2-(1.90 \%)$ & 0 \\
\hline Fish, meat and poultry & $32-(30.47 \%)$ & $29-(27.61 \%)$ & $8-(7.61 \%)$ & $1-(0.95 \%)$ \\
\hline Milk and milk products & $92-(87.61 \%)$ & $13-(12.38 \%)$ & 0 & 0 \\
\hline Fats and oils & $41-(39.04 \%)$ & $36-(34.28 \%)$ & $28-(26.66 \%)$ & 0 \\
\hline Sugar group & $68-(64.76 \%)$ & $20-(19.04 \%)$ & $17-(16.19 \%)$ & 0 \\
\hline Beverages and carbonated drinks & $99-(100 \%)$ & $6-(5.71 \%)$ & 0 & 0 \\
\hline
\end{tabular}

\section{Nutritional intake of the women's}

Majority of the food groups consumed daily by the participants were cereals $(96.19 \%)$, followed by pulses $(64.76 \%)$ which were consumed majorly on $2-3$ times in a week. Fruits $(45.71 \%)$ and vegetables $(63.80 \%)$ were consumed weekly. Milk and milk products were consumed daily $(87.61 \%)$ (Table 3$)$. 
Table-4: Nutritional status of the women from the different villages

\begin{tabular}{|c|c|c|}
\hline Villages & BMI & Category \\
\hline $\begin{array}{l}\text { Binkadakatti } \\
n=14\end{array}$ & $\begin{array}{l}6-(42.85 \%)-\text { Underweight } \\
5-(35.71 \%)-\text { Normal } \\
3-(21.42 \%)-\text { Pre - obese }\end{array}$ & $\begin{array}{l}13-(92.85 \%)-\text { Normal } \\
1-(7.14 \%)-\text { Anemic }\end{array}$ \\
\hline $\begin{array}{l}\text { Hulkoti } \\
\mathrm{n}=35\end{array}$ & $\begin{array}{l}12-(34.28 \%)-\text { Underweight } \\
16-(45.71 \%)-\text { Normal } \\
4-(11.42 \%)-\text { Overweight } \\
3-(8.57 \%)-\text { Pre - obese }\end{array}$ & $\begin{array}{l}30-(85.71 \%)-\text { Normal } \\
5-(14.28 \%)-\text { Anemic }\end{array}$ \\
\hline $\begin{array}{l}\text { Kalasapur } \\
\mathrm{n}=14\end{array}$ & $\begin{array}{l}2-(14.28 \%)-\text { Underweight } \\
9-(64.28 \%)-\text { Normal } \\
3-(21.42 \%)-\text { Overweight }\end{array}$ & $\begin{array}{l}10-(71.42 \%)-\text { Normal } \\
4-(28.57 \%)-\text { Anemic }\end{array}$ \\
\hline $\begin{array}{l}\text { Kurthkoti } \\
\mathrm{n}=28\end{array}$ & $\begin{array}{l}11-(39.28 \%)-\text { Underweight } \\
17-(60.71 \%)-\text { Normal }\end{array}$ & $\begin{array}{l}23-(82.14 \%)-\text { Normal } \\
5-(17.85 \%)-\text { Anemic }\end{array}$ \\
\hline $\begin{array}{l}\text { Nagavi } \\
\mathrm{n}=14\end{array}$ & $\begin{array}{l}7-(50 \%)-\text { Underweight } \\
7-(50 \%) \text { - Normal }\end{array}$ & $\begin{array}{l}12-(85.71 \%)-\text { Normal } \\
2-(14.28 \%)-\text { Anemic }\end{array}$ \\
\hline Total $=105$ & $\mathrm{UW}-38, \mathrm{~N}-54, \mathrm{OW}-7, \mathrm{PO}-6$ & $\mathrm{~N}-88, \mathrm{~A}-17$ \\
\hline
\end{tabular}

(UW- underweight, N- normal, OW- over weight, PO- pre obese, A- anemic)

\section{Nutritional status of the women}

It shows that most of the participants $54(35.71 \%)$ comes under the BMI range of normal, followed by underweight $38(36.19 \%)$. When compared according to the village it shows that participants from the village Hulkoti which is a developed place when compared with other villages were under the sedentary lifestyle with 4 participants who were overweight and 3 who were pre-obese, followed by Binkadakatti (Table 4).

\section{DISCUSSION}

In the current, it was found that the majority of the participant belonged to the low and upper lower and lower middle income. A similar study conducted in the Mysuru district of Karnataka which was carried out with an interest to collect data regarding the on the nutritional and food security status of women by Prakash J, showed that majority of subjects belonged to low income group similar to our study [9].

Nutritional status is directly related to the health of the population and is influenced by levels of education, the standard of living and social status. In the current study majority of the participants were lacking in the consumption of energy, followed by protein intake. A similar study conducted in the district of Vijayapur, Karnataka on the assessment of nutritional status and dietary diversity of the 160 rural and urban household by Vijayalakshmi \& Khed S. V. That the energy intake and other nutrient intake were lower than ICMR recommended. Dietary diversity result indicates urban households consume more diverse food items as compare to rural households [10]. Another study conducted at Nepal found the same results [11].

In the present study majority of the participants, nutritional status was normal among women, a similar cross-sectional study conducted in the selected community people at Orissa found similar findings [12]. Another study conducted at Kerala and U $\mathrm{S}$ A found similar findings [13].

In the present study, it was found that $1 / 3^{\text {rd }}$ of the women's are underweight, a similar study conducted Lagos state of Africa found the same findings [14]. A similar study conducted by the National Institute of Nutrition found the same findings [15].

\section{CONCLUSION}

Most of the participants were from the age group of 21 to 30 years, with a higher education background of secondary school. The main food groups consumed daily were cereals followed by pulses. The energy, protein intake was less than the recommended and fat intake was more than the recommended. Nutritional status was normal among $51 \%$ of all the women, while $36 \%$ were underweight. They were lacking in the consumptions of fruits, vegetables and most of the participant's water consumption is also less.

\section{ACKNOWLEDGEMENT}

Gratitude can never be expressed in words but this is only the deep appreciation, which makes the words flow from one's inner heart. Any accomplishment requires the effort of many people. I feel it is a great privilege to express my heartfelt thanks and deep sense of gratitude to a Dr Suresh Kishanrao, Honorary professor and Prof.Suresh V Nadagoudar, Acting ViceChancellor and Registrar of our University.

\section{REFERENCES}

1. Akhter, S., Wohab, M.A. (2006). Health, Nutrition and Human Resource Development: a Crucial Link. BRAC Univ J, 3(2):125-32.

2. Abnet, A.J., Christian, C., Jiyoung, A. (1989). Cross and RS, Summary. Dietary Intake and Nutritional Status: Trends and Assessment. Heal Natl Res Counc Comm Diet [Internet]. 1989;189- 
98. Available from: https://www.ncbi.nlm.nih.gov/books/NBK218765/

3. Prabhat, A., \& Begum, K. (2012). Food consumption pattern and nutritional status of women laborers from coastal areas of Karnataka. National Journal of Community Medicine, 3(2), 321-325.

4. Bhandari, S., Sayami, J. T., Thapa, P., Sayami, M., Kandel, B. P., \& Banjara, M. R. (2016). Dietary intake patterns and nutritional status of women of reproductive age in Nepal: findings from a health survey. Archives of public health, 74(1), 1-11.

5. Grieger, J. A., Grzeskowiak, L. E., Bianco-Miotto, T., Jankovic-Karasoulos, T., Moran, L. J., Wilson, R. L., \& Myers, J. (2018). Pre-pregnancy fast food and fruit intake is associated with time to pregnancy. Human Reproduction, 33(6), 1063 1070.

6. Khed, V. (2018). Nutritional Status and Dietary Diversity of Households in Vijayapura District of Karnataka (No. 2058-2018-5240).

7. http://www.fao.org/3/a-i3862e.pdf

8. Hagan, OC, Nsiah, P., Obiri-Yeboah, D., Yirdong, F., Annan, I., Eliason, S., \& Nuvor, SV (2018). Impact of universal childhood vaccination against hepatitis B in Ghana: A pilot study. Journal of public health in Africa,

9. Imamura, F., Micha, R., Khatibzadeh, S., Fahimi, S., Shi, P., Powles, J., \& Global Burden of Diseases Nutrition and Chronic Diseases Expert Group (NutriCoDE. (2015). Dietary quality among men and women in 187 countries in 1990 and 2010: a systematic assessment. The lancet global health, 3(3), e132-e142.

10. Medical Research Council. Unhealthy eating habits outpacing healthy eating patterns in most world regions Available at: http://www.mrc.ac.uk/newsevents/news/unhealthy-eating-habitsoutpacinghealthy-eating-patterns-in-most-world-regions/. Accessed on: 28th September.

11. Fasola, O., Abosede, O., \& Fasola, F. A. (2018). Knowledge, attitude and practice of good nutrition among women of childbearing age in Somolu Local Government, Lagos State. Journal of public health in Africa, 9(1).

12. Vatsala, L., Prakash, J., \& Prabhavathi, S. (2017). Food security and nutritional status of women selected from a rural area in South India. Journal of Food, Nutrition and Population Health, 1(2), 1-8.

13. Prabhat, A., \& Begum, K. (2012). Food consumption pattern and nutritional status of women laborers from coastal areas of Karnataka. National Journal of Community Medicine, 3(2), 321-325.

14. Rao, K. M., Balakrishna, N., Arlappa, N., Laxmaiah, A., \& Brahmam, G. N. V. (2010). Diet and nutritional status of women in India. Journal of Human Ecology, 29(3), 165-170.

15. Rout, N. R. (2009). Food consumption pattern and nutritional status of women in Orissa: A ruralurban differential. Journal of Human Ecology, 25(3), 179-185. 